\title{
"Evaluation of social and economic insecurity risks for employees during structural transformations in the modern labor market"
}

\begin{tabular}{|c|c|}
\hline AUTHORS & $\begin{array}{l}\text { Olga Novikova } \text { https://orcid.org/0000-0002-8263-1054 } \\
\text { R http://www.researcherid.com/rid/G-9667-2018 } \\
\text { Larisa Shamileva (D https://orcid.org/0000-0003-4738-0728 } \\
\mathbb{R} \text { http://www.researcherid.com/rid/Q-1860-2018 }\end{array}$ \\
\hline ARTICLE INFO & $\begin{array}{l}\text { Olga Novikova and Larisa Shamileva (2020). Evaluation of social and economic } \\
\text { insecurity risks for employees during structural transformations in the modern } \\
\text { labor market. Social and labour relations: theory and practice, 10(1), 1-10. } \\
\text { doi:10.21511/slrtp.10(1).2020.01 }\end{array}$ \\
\hline DOI & http://dx.doi.org/10.21511/sIrtp.10(1).2020.01 \\
\hline RELEASED ON & Friday, 10 April 2020 \\
\hline RECEIVED ON & Thursday, 06 February 2020 \\
\hline ACCEPTED ON & Friday, 28 February 2020 \\
\hline LICENSE & $\begin{array}{l}(c)) E Y \\
\text { This work is licensed under a Creative Commons Attribution } 4.0 \text { International } \\
\text { License }\end{array}$ \\
\hline JOURNAL & "Social and labour relations: theory and practice" \\
\hline ISSN PRINT & $2410-4752$ \\
\hline ISSN ONLINE & 2415-3389 \\
\hline PUBLISHER & LLC "Consulting Publishing Company "Business Perspectives" \\
\hline FOUNDER & $\begin{array}{l}\text { State Higher Educational Establishment "Kyiv National Economic University } \\
\text { named after Vadym Hetman", Social and Labour Relations Institute }\end{array}$ \\
\hline$\sigma^{0}$ & 三:- \\
\hline NUMBER OF REFERENCES & NUMBER OF FIGURES \\
\hline 16 & 0 \\
\hline
\end{tabular}

(c) The author(s) 2022. This publication is an open access article. 


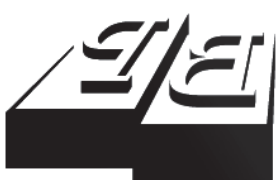

BUSINESS PERSPECTIVES

Publisher

LLC "CPC "Business Perspectives" Hryhorii Skovoroda lane, 10, Sumy, 40022, Ukraine www.businessperspectives.org

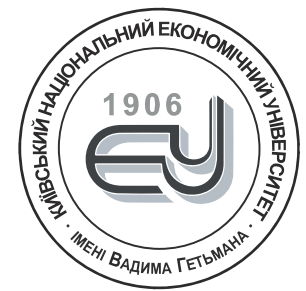

\section{HETMAN KNEU}

Founder

State Higher Educational Establishment "Kyiv National Economic University named after Vadym Hetman",

Prospect Peremogy, 54/1,

Kyiv, 03057, Ukraine

https://kneu.edu.ua/

Received on: 6th of February, 2020 Accepted on: 28th of February, 2020 Published on: 10th of April, 2020

(c) Olga Novikova,

Larisa Shamileva, 2020

Olga Novikova, Doctor of Economics, Professor, Deputy Director for Research, Institute of Industrial Economics of National Academy of Sciences of Ukraine, Ukraine.

Larisa Shamileva, Candidate of Economics, Associate Professor, Institute of Industrial Economics of National Academy of Sciences of Ukraine, Ukraine.

\section{(c) (i)}

This is an Open Access article, distributed under the terms of the Creative Commons Attribution 4.0 International license, which permits unrestricted re-use, distribution, and reproduction in any medium, provided the original work is properly cited.

\section{EVALUATION OF SOCIAL AND ECONOMIC INSECURITY RISKS FOR EMPLOYEES DURING STRUCTURAL TRANSFORMATIONS IN THE MODERN LABOR MARKET}

\begin{abstract}
This article systematizes main factors of socio-economic insecurity aggravation for employees during structural transformations, which take place on the modern labour market. These factors are related to inefficient employment and low level of labor productivity, regressive mobility of the employed population, loss of educational and labor potential of the country, low competitiveness of its labor force both in domestic and foreign labor markets, increase of unemployment among able-bodied people and informal employment, especially among young people and higher-level professionals, widening the gender gap in the employment structure to the benefit of older age groups. A methodological implementation of the assessments of social and economic insecurity risks for employees has been developed and verified in the study. It is based on comparing performance levels in particular components in specific time intervals.

It is substantiated that, due to changes in the structure of the labor market and in the system of social and labor relations, the main factors of increasing the vulnerability of employees are related to the deindustrialization of the national economy, which is accompanied by formation of a regressive educational and professional structure of employed, as well as by the loss of motivation for productive work and increase in the professional level, reduction of social protection of employees, the growth of informal employment among young people and highly qualified specialists. High scale of labor migration and low demand for specialists in the internal labor market, low wages lead to loss of labor and educational potential and narrow the conditions for the development and realization of the country's human capital.
\end{abstract}

Keywords

JEL Classification labor market, transformation, employment, labor and educational potential, risks of social and economic insecurity, evaluation J60, O15
О. Ф. Новікова (Україна), Л. Л. Шамілева (Україна)

\section{ОЦІНЮВАННЯ РИЗИКІВ СОЦІАЛЬНО- ЕКОНОМІЧНОÏ НЕЗАХИЩЕНОСТІ ЗАЙНЯТИХ В УМОВАХ СТРУКТУРНИХ ТРАНСФОРМАЦИЙ СУЧАСНОГО РИНКУ ПРАЦІ}

\section{Анотація}

В статті систематизовані основні чинники посилення соціально-економічної незахищеності зайнятого населення в умовах структурних трансформацій, які відбуваються на сучасному ринку праці. Вони пов'язані з неефективною зайнятістю та низьким рівнем продуктивності праці, регресивною мобільністю зайнятого населення, втратою освітнього та трудового потенціалу країни, конкурентоспроможності іiі робочої сили як на внутрішньому, так і на зовнішніх ринках праці, зростанням безробіття серед працездатного контингенту та неформальної зайнятості, особливо серед молоді та спеціалістів вищої кваліфікаціі, посиленням міжпоколінського розриву в структурі зайнятого населення на користь старших вікових груп. Методику оцінки ризиків соціально-економічної незахищеності зайнятих, що розроблено та апробовано авторами, представлено в статті. Вона базується на співставленні рівнів показників за визначеними напрямками в окремі проміжки часу. 
Визначено, що внаслідок трансформацій в структурі ринку праці та в системі соціально-трудових відносин основні чинники посилення незахищеності зайнятих пов'язані з деіндустріалізацією національної економіки, яка супроводжується формуванням регресивної освітньо-професійної структури зайнятого населення; втратою мотивації до продуктивної праці та підвищення професійного рівня; зниженням соціального захисту працюючих; зростанням неформальної зайнятості, особливо серед молоді та спеціалістів вищої кваліфікації. Високий рівень трудової міграції та низький попит на спеціалістів на внутрішньому ринку праці, низький рівень оплати праці призводять до втрати трудового та освітнього потенціалу та звуження умов для розвитку та реалізації людського капіталу країни.

Ключові слова

ринок праці, трансформації, зайнятість, трудовий та освітній потенціал, ризики соціальноекономічної незахищеності, оцінювання

Класифікація JEL J60, O15

\section{ВСТУП}

Трансформація ринку праці визначається рівнем перетворень за кожним його елементом, зокрема попитом та пропозицією та їх збалансованістю, професійно-кваліфікаційною структурою зайнятих, змінами в системі соціально-трудових відносин, ефективністю використання витрат праці, неформальною зайнятістю та рівнем трудової міграції тощо. Як наслідок, структурні зміни на ринку праці характеризуються зміною рівнів зайнятості, зміною безпосередньо змісту та характеру праці, сегментів ринку праці та структури робочих місць, появою нових форм зайнятості та зміною вимог до професійних компетенцій працівників, які одночасно обумовлюють посилення незахищеності зайнятих.

Найбільш вагомі зовнішні та внутрішні чинники структурних змін на ринку праці пов’язані, в першу чергу, з глобалізаційними процесами, рівнем економічного розвитку країни з урахуванням циклічності та ризикованості, рівнями технологічного укладу та технологічними змінами процесів виробництва, процесами, пов'язаними з інформатизацією та цифровізацією економіки. Негативні наслідки цих процесів в системі соціально-трудових відносин супроводжуються зростанням соціально-економічної незахищеності працюючих та створюють умови для формування та прояву соціальних ризиків. Вони пов’язані в першу чергу з незахищеністю зайнятості в цілому та на робочих місцях відповідно до кваліфікаційного, професійного та освітнього рівня, відсутністю можливостей одержати гідну оплату праці, працювати на робочих місцях з безпечними умовами праці тощо. На рівні суспільства ризики пов'язані зі звуженням умов формування та реалізації людського капіталу, вимиванням середнього класу в країні та посиленням регресивної соціальної мобільності. Постаріння зайнятого населення i, як наслідок, звуження контингенту зайнятих з трудовими компетенціями, які відповідають сучасним вимогам, невідповідність рівня освіти та рівням зайнятості за професійними групами, зниження мотивації до підвищення рівнів кваліфікації, звуження умов для формування сучасного працівника інноваційного типу доповнюються підвищенням міграційних настроїв, вимиванням найбільш креативного трудового та освітнього потенціалу країни.

Такий стан потребує детального аналізу та оцінки структурних зрушень у сфері зайнятості та визначення рівнів соціально-економічної незахищеності зайнятого населення за умов трансформацій ринку праці, що й обумовлює актуальність дослідження.

\section{1. ЛІТЕРАТУРНИЙ ОГЛЯА}

Проблемам структурних трансформацій ринку праці та зайнятості присвячені наукові дослідження провідних вітчизняних науковців, серед яких можна відмітити наукові доробки Колота [6], Лібанової [9], Петрової [13], Лісогор [10], Грішнової [3], Антонюк [1], Ільїч [4] та ін. Структурні трансформації транзитивного ринку праці з визначенням освітньо-кваліфікаційного дисбалансу зайнятості досліджує Ільїч [4]. Проблеми різновекторної зміни зайнятості за умов становлення нової економіки з визначенням суперечливих структурних зрушень на ринку праці в Україні та європейських країнах розкриваються в наукових публікаціях Колота [6], Антонюк [1], Петрової [13]. Сучасні особливості структурних трансформацій ринку праці та їх чинники при переході до цифрової економіки знайшли своє висвітлення в наукових роботах Колота, Герасименко [6, 7], Азьмук [2], в яких розкриваються нові можливості та загрози, які виникають в системі соціально-трудових відносин за умови цифровізації економіки, 
поширення сучасних нетрадиційних форм зайнятості, визначені основні соціально-економічні наслідки таких трансформацій. На основі наукового усвідомлення та обгрунтування тенденцій змін зайнятості в результаті поширення наукоємних та інформаційних технологій в наукових працях Інституту демографії та соціальних досліджень обгрунтовано напрями регулювання сфери зайнятості та визначено соціальні ризики і загрози інноваційної зайнятості [9].

Не зважаючи на досить широкий спектр наукових досліджень проблем структурних зрушень на ринку праці залишаються невизначеними основні соціально-економічні ризики зайнятості за умов трансформаційних процесів в системі соціально-трудових відносин та на ринку праці. Систематизація та кількісне визначення рівнів соціально-економічної незахищеності зайнятих та чинників їх зміни обумовлює актуальність та визначає мету дослідження.

\section{2. МЕТА ДОСЛІДЖЕННЯ}

Метою статті $€$ висвітлення науково-методичного обгрунтування та розроблення методики оцінки ризиків соціально-економічної незахищеності зайнятих за умов структурних трансформацій ринку праці з визначенням тенденцій та їх чинників зміни для надання рекомендації попередження та мінімізації їх негативних наслідків.

\section{3. РЕЗУЛЬТАТИ}

Структурні трансформації на ринку праці формують низку соціальних ризиків, які визначаються за такими напрямками:

- неефективна зайнятість;

- низький рівень продуктивності праці та негативні тенденції їі зміни;

- регресивна мобільність зайнятого населення супроводжується зниженням частки працівників 3 більш високим рівнем продуктивної праці;

- суттєва втрата освітнього потенціалу на внутрішньому ринку праці, яка обумовлена зміною зайнятості за освітньо-професійним рівнем;

- супроводжується суттєве зростання рівня безробіття працездатного населення при незначне зменшення ризику незахищеної зайнятості;

- збільшення ризиків незахищеної зайнятості при зростанні частки працівників, які не охоплені колективними договорами,

- зростання неформальної зайнятості молоді та спеціалістів вищої кваліфікації;

- посилення зростання міжпоколінського розриву зайнятого населення на користь старших вікових груп;

- збільшення ризику незахищеності оплати праці;

- суттєве зростання ризику втрати освітнього потенціалу зайнятого населення внаслідок незатребуваності на внутрішньому ринку праці та неформальної зайнятості працівників з вищою освітою;

- зростання ризиків в трудовій сфері внаслідок трудової міграції.

Узагальнення основних тенденцій структурних зрушень на ринку праці дає можливість для систематизації основних видів ризиків соціально-економічної незахищеності зайнятого населення, серед яких визначаються такі:

1. Ризики зміни зайнятості внаслідок деіндустріалізації економіки та регресивної мобільності зайнятого населення $\left(I_{\text {зайн. }}\right)$.

2. Ризики незахищеної зайнятості $\left(I_{\text {неззайн. }}\right)$ внаслідок поширення зайнятості в неформальному секторі та прекарізації економічно активного населення (ЕАН).

3. Ризики зниження ефективності використання витрат живої праці з урахуванням наукоємності видів економічної діяльності (ВЕД) та технологічного рівня видів промислової діяльності $\left(I_{\text {еф.зайн. }}\right)$. 
4. Ризики незахищеності оплати праці $\left(I_{\text {нез.опл. }}\right)$.

5. Ризики втрати освітнього потенціалу та людського капіталу $\left(I_{\text {втр.осв.пот. }}\right)$.

6. Ризики в трудовій сфері внаслідок трудової міграції $\left(I_{\text {тр.мігр. }}\right)$.

Кількісна оцінка соціальних ризиків базується в основномуна трьохметодичнихпідходахдоїх визначення. Перший пов язаний з оцінкою вірогідності прояву чи реалізації конкретного виду соціального ризику за певних умов. Другий, як об'єктивне доповнення першого, включає оцінку можливих втрат в вартісному, натуральному або трудовому виміру за умови прояву конкретного виду ризику. Застосування цих двох підходів потребує значних обсягів статистичної інформації та її економіко-математичної обробки.

Найбільш популярним є в останні роки третій підхід, який визначає та кількісно оцінює не скільки безпосередньо рівень соціального ризику, а його зміну та тенденції такої зміни. Змістовно їхінтерпретують як зміни рівнів ризиків або рівнів економічної чи соціальної незахищеності за умови прояву ризика конкретного виду $[12,15,16]$.

Алгоритм визначення ризиків трудової сфери за умови трансформаційних процесів передбачає за кожним 3 шести наведених видів ризиків розрахування відповідних субіндесів $\left(I_{i}\right)$ за такими співвідношеннями (1):

$$
I_{i}=\sum_{j=1}^{n_{i}} W_{i j} \sqrt{\prod_{j=1}^{n_{i}} K_{i j}^{W_{i j}}}=\sum_{j=1}^{n_{i}} W_{i j} \sqrt{K_{i 1}^{W_{i, 1}} \cdot K_{i 2}^{W_{i, 2}} \cdot \ldots \cdot K_{i, n_{i}}^{W_{1, n_{i}}}}
$$

де $K_{i j}$ - коефіцієнти (темпи зміни) $j$-го індикатора визначення субіндексу зміни $i$-го ризику, $j=\overline{1, n_{i}}$, $K_{i j}=\frac{X_{i j, t}}{X_{i j, t-1}}$ (для стимуляторів), $K_{i j}=\frac{X_{i j, t-1}}{X_{i j, t}}$ (для дестимуляторів), $X_{i j, t}, X_{i j, t-1}$ - значення $j$-го

індикатора $i$-го субіндексу, відповідно, в $t$-му та $(t-1)$-му році, $n_{i}$ - кількість індикаторів визначення $i$-го виду ризику, $i$ - номер ризику, $i=\overline{1.6}, W_{i j}$ - вагові коефіцієнти $j$-го індикатору виміру $i$-го виду ризику, які відповідають частці населення, на яке поширюється конкретний вид ризику.

Узагальнений індекс зміни рівнів соціальних ризиків в трудовій сфері за умови трансформацій соціальнотрудових відносин та зайнятості розраховується за середньою геометричною зваженою з визначених субіндексів (2):

$$
I_{\text {соц.риз. }}=\sum \sqrt[W_{i}]{I_{1}^{W_{1}} \cdot I_{2}^{W_{2}} \cdot \ldots \cdot I_{6}^{W_{6}}},
$$

де $W_{i}$ - вагові коефіцієнти $i$-го виду ризику, які визначаються також за допомогою часток населення, на яке поширюється $i$-й вид ризику.

За змістом наведені індекси $є$ коефіцієнтами або темпами зміни відповідного ризику. Виходячи з того, що всі субіндекси визначаються на підгрунті співставлення індикаторів їх визначення та формування за два роки, тобто 2018 р. в порівнянні з 2013 р. ${ }^{1}$, та вимірюють зміни рівнів ризиків або рівнів незахищеності внаслідок прояву ризику, змістовна їх характеристика така: при $I_{i}>100 \%$ рівень ризику або незахищеності зріс, а при $I_{i}<100 \%$, відповідно, знизився.

Інформаційне забезпечення за кожним індикатором визначення та виміру ризиків базується на даних офіційної статистики, яка наведена в відповідних статистичних збірниках та статистичних бюлетенях, безпосередніх додаткових розрахунках за окремими показниками, наприклад, середньорічні темпи зміни продуктивності праці, коефіцієнти децільної диференціації, обсяги трудового потенціалу та інше.

1. Ризики зміни зайнятості внаслідок деіндустріалізації економіки та регресивної мобільності зайнятості формуються на підгрунті зміни визначених таких індикаторів та кількісної оцінки зміни рівнів:

Вибір 2013 р. в якості бази порівняння пов’язаний з тим, що це був останній «мирний» рік до подій 2014-2019 рр. 
- зміни частки зайнятих в промисловості по відношенню до всього зайнятого населення;

- інтенсивності зміни рівня зайнятості в промисловості;

- частки зайнятих в первинному секторі економіки;

- зміни зайнятості за окремими видами промислової діяльності з урахуванням їх технологічного рівня, в тому числі:

a) високотехнологічний;

б) середньовисокий;

в) середньонизький та низький;

- частки зайнятих на великих та середніх підприємствах:

а) в цілому за всіма ВЕД;

б) в промисловості;

- зміна зайнятості в молодих працездатних вікових групах;

- зростання показника розриву поколінь в структурі зайнятого населення.

$$
\begin{aligned}
& \mathrm{I}_{\text {зайн. }}=1.101^{0.05885} \cdot 1.02426^{0.05885} \cdot 1.02273^{0.06647} \cdot 0.927773^{0.0197} \cdot 0.9556^{0.086} \\
& \cdot 0.994475^{0.282} \cdot 1.1926^{0.0352} \cdot 1.3570^{0.019} \cdot 1.0643^{0.13036} \cdot 1.13125^{0.243565}= \\
& =1.0068 \cdot 1.0014 \cdot 1.0015 \cdot 0.99858 \cdot 0.9961 \cdot 0.99844 \cdot 1.00622 \cdot 1.00582 . \\
& \cdot 1.0082 \cdot 1.03=1.053, \text { aбо } 105.3 \% \text {. }
\end{aligned}
$$

Загальне зростання ризику зміни зайнятості внаслідок деіндустріалізації економіки та регресивної мобільності зайнятого населення за 2013-2018 рр. складає 5.3\% та обумовлено такими чинниками:

- деіндустріалізація економіки супроводжується зростанням ризику регресивної мобільності зайнятого населення в основному за рахунок зниження рівня зайнятості в промисловості за п'ять років на $10.1 \%$ та зростання інтенсивності зниження зайнятості в промисловості в 2013-2018 pр. в порівнянні з 2010-2013 рр. на 2.4\%;

- деіндустріалізація супроводжується перетіканням зайнятого населення в первинний сектор економіки, за рахунок цього чинника ризик зріс на $2.3 \%$;

- падіння зайнятості на великих та середніх підприємствах, як наслідок та умови деіндустріалізації, визначають зростання ризику на 19.3\% (за всіма ВЕД) та на 35.7\% - за видами економічної діяльності промисловості;

- збільшення рівнів ризику в сфері зайнятості пов’язано з падінням зайнятості серед молоді (на 6.4\%), що формує розрив між поколіннями зайнятого населення;

- зворотня тенденція склалася запоказниками, якіхарактеризують зростання зайнятостіз урахуванням технологічного рівня промислової діяльності, внаслідок цих чинників рівні ризику знизились на 7.2\% (за видами діяльності з високотехнологічним рівнем) та на 4.6\% (за середньовисоким рівнем).

2. Ризики незахищеної зайнятості внаслідок прекарізації ЕАН формуються на множині таких індикаторів:

- зайнятість в неформальному секторі, в тому числі в молодому працездатному віці;

- безробіття в працездатному віці;

- астки штатних працівників, яким нарахована заробітна плата в межах мінімальної;

- частки працівників, які не охоплені колективними договорами;

- частки працівників, які працюють неповний робочий день (тиждень) та які перебувають у відпустках без збереження оплати праці;

- загального рівня прекарізації ЕАН.

$\mathrm{I}_{\text {нез.зайн. }}=0.9^{0.2295} \cdot 1.03^{0.00174} \cdot 1.09^{0.001166} \cdot 1.222^{0.08672} \cdot 1.163^{0.0266}$.

$\cdot 1.168^{0.11187} \cdot 0.86^{0.04317} \cdot 0.961^{0.499234}=0.97611 \cdot 1.000051 \cdot 1.0001 \cdot$

$\cdot 1.017538 \cdot 1.004025 \cdot 1.017524 \cdot 0.99351 \cdot 0.98034=0.9885$, або $98.85 \%$. 
Рівень незахищеної зайнятості в цілому знизився на 1.15\% за останні п’ять років. Основні чинники такої позитивної тенденції обумовлені таким:

- зменшення зайнятості в неформальному секторі на 10\%;

- $\quad$ на $14.0 \%$ відбулося зменшення частки працівників, які працюють неповний робочий день (тиждень) та які перебувають у безоплатних відпустках;

- зниження загального рівня прекарізації ЕАН на 3.9\%.

Одночасно за низкою індикаторів зміни ризику склалася протилежна тенденція, яка обумовлює суттєве збільшення рівня ризику незахищеності зайнятості. Серед найбільш вагомих визначаються такі:

- $\quad$ зростання на $22.2 \%$ рівня безробіття працездатного населення;

- збільшення частки працівників на $16.8 \%$, які не охоплені колективними договорами;

- на $16.3 \%$ зросла частка штатних працівників, яким нарахована заробітня плата в межах мінімальної.

3. Ризики зміни ефективності використання витрат робочої сили визначаються на наведеній множині індикаторів:

- зміни (затухання) середньорічних темпів продуктивності праці:

а) в цілому за всіма ВЕД;

б) за наукоємними видами економічної діяльності;

в) за видами промислової діяльності з урахуванням технологічного рівня (високотехнологічний, середньовисокий, середньонизький та низький);

- співвідношення продуктивності праці за окремими ВЕД до її значення по економіці в цілому.

$$
\begin{aligned}
& \mathrm{I}_{\text {еф.зайн. }}=1.0072^{0.581} \cdot 1.053^{0.0912} \cdot 0.863^{0.103} \cdot 1.085^{0.0912} \cdot 1.1355^{0.00483} \cdot 1.141^{0.0201} \\
& \cdot 1.1265^{0.01027} \cdot 1.1573^{0.056} \cdot 1.05^{0.0424}=1.0042 \cdot 1.00470 \cdot 0.98494 \cdot 1.0075 . \\
& \cdot 1.000614 \cdot 1.002655 \cdot 1.001224 \cdot 1.00821 \cdot 1.00207=1.016, \text { або } 101.6 \% .
\end{aligned}
$$

Зростання ризиків зниження ефективності праці в 2013-2018 рр. в порівнянні з 2010-2013 рр. складає 1.6\% внаслідок таких чинників:

- затухання темпів приросту продуктивності праці на 8.5\%;

- суттєве зниження інтенсивності зміни продуктивності праці в промисловості з урахуванням технологічногорівня промисловоїдіяльності, зокрема, з високим рівнем-на $13.55 \%$, зсередньовисоким - на $14.1 \%$, з середньонизьким - на $12.65 \%$, з низьким рівнем - близько $16 \%$;

- $\quad$ на 5.0\% знизилися середньорічні темпи розвитку продуктивності праці за наукоємними видами економічної діяльності.

4. Ризики незахищеності оплати праці формуються за такими індикаторами:

- частки оплати праці в ВВП;

- рівня диференціації працівників за розмірами середньомісячної заробітної плати;

- частки працівників з оплатою праці нижче середнього рівня;

- частки працівників, яким нарахована заробітна плата в межах мінімальної;

- частки працівників з контингенту зайнятого населення, яким оплачено менше половини робочого часу.

Рівень незахищеності оплати праці зріс за 2013-2018 рр. на 3.5\%. Основні чинники, які визначають таке збільшення, пов'язані з суттєвим зниженням частки оплати праці в ВВП (на 20.7\%), значним (на 16.3\%) зростанням частки працівників, яким нарахована зарплата в межах мінімальної та збільшенням частки 
працівників, яким сплачено менше половини робочого часу. Приріст складає майже $6.0 \%$. Одночасно суттєво зменшився рівень диференціації зайнятого населення за оплатою праці на підгрунті децільного коефіцієнту диференціації. За останні п’ять років це зниження складає $24.0 \%$.

$$
\begin{aligned}
& \mathrm{I}_{\text {нез.опл. }}=1.207^{0.4988} \cdot 0.76^{0.23572} \cdot 1.0105^{0.23572} \cdot 1.1633^{0.013134} \cdot 1.0595^{0.016626}= \\
& =1.09839 \cdot 0.93736 \cdot 1.002465 \cdot 1.002 \cdot 1.00096=1.035, \text { або } 103.5 \% .
\end{aligned}
$$

5. $\quad$ Ризики втрати освітнього потенціалу та людського капіталу визначаються на підгрунті таких індикаторів:

- загального рівня невідповідності зайнятості за професійними групами та освітнім рівнемпрацівників за дипломом (посвідченням);

- втрати освітнього потенціалу найбільш кваліфікованих працівників (професіоналів та фахівців);

- втрати та незатребуваність освітнього потенціалу внаслідок трудової міграції;

- втрати освітнього потенціалу внаслідок неформальної зайнятості працівників з вищою освітою;

- втрати освітнього потенціалу на внутрішньому ринку праці.

$$
\begin{aligned}
& \mathrm{I}_{\text {втр.осв.пот. }}=1.024^{0.55} \cdot 1.0174^{0.034} \cdot 1.23^{0.3} \cdot 1.308^{0.116}= \\
& =1.013 \cdot 1.000587 \cdot 1.064 \cdot 1.0316=1.113, \text { або } 111.3 \% .
\end{aligned}
$$

Ризики втрати освітнього потенціалу і, як наслідок, людського капіталу зросли за останні п’ять років на 11.3\% внаслідок таких чинників:

- незатребуваності освітнього потенціалу на внутрішньому ринку - втрати складають 23.0\%;

- зростання неформальної зайнятості працівників з вищою освітою (повною, базовою, неповною) майже на 31.0\% визначають збільшення рівня ризику;

- $\quad$ втрати освітнього потенціалу найбільш кваліфікованих працівників (професіоналів та фахівців), яка зросла на $1.74 \%$, а загальний рівень невідповідності зайнятості за професійними групами та освітнім рівнем супроводжується зростанням ризику на $1.24 \%$.

6. Ризики втрати трудового та освітнього потенціалу внаслідок трудової міграції визначаються за наведеними складовими та індикаторами їх виміру:

- обсяги трудової міграції ,в тому числі:

a) за офіційними статистичними даними;

б) за експертними оцінками;

- зміни рівнів трудової міграції в загальному обсязі ЕАН в віці 15-70 років;

- обсяги освітньої міграції;

- втрати трудового потенціалу країни внаслідок трудової міграції;

- умовні втрати трудового потенціалу за рахунок освітньої міграції;

- співвідношення погодинної оплати праці (в євро) в країнах Європейського Союзу та України;

- доступність трудових мігрантів до соціального страхування;

- міграційні настрої населення, - «хотіли б виїхати» (2013 р.), та «замислювались над від’їздом» (2018р.).

$\mathrm{I}_{\text {Tp.Mirp. }}=$

$=\sqrt[1.4642]{1.1^{0.131} \cdot 1.2^{0.131} \cdot 2.07^{0.006} \cdot 1.133^{0.137} \cdot 1.064^{0.66} \cdot 1.005^{0.131} \cdot 2.03^{0.006} \cdot 0.946^{0.131} \cdot 0,967^{0.00019} \cdot 1.46^{0.131}}=$

$=\sqrt[1.4642]{1.01256 \cdot 1.02417 \cdot 1.00437 \cdot 1.01729 \cdot 1.0418 \cdot 1.00065 \cdot 1.004257 \cdot 0.99275 \cdot 0.999994 \cdot 1.0508}=$

$=\sqrt[1.4642]{1.157177}=1.105$, або $110.5 \%$.

Зростання ризиків в трудовій сфері внаслідок трудової та освітньої міграції за останні п’ять років складає $10.5 \%$. 
Основні чинники, які обумовили визначене зростання, пов’язані із таким:

- суттєве зростання трудової міграції (за офіційними даними) на 10.2\%;

- більш ніж вдвічі зросла освітня міграція - приріст складає 108\%;

- визначені обсяги трудової та освітньої міграції супроводжуються зростанням обсягів втрати трудового (на 6.4\%) та освітнього (на 108\%) потенціалів;

- невідповідність зайнятості трудових мігрантів рівням їх освіти та кваліфікації супроводжується зростанням рівня ризику на $0.5 \%$;

- ризики втрати трудового потенціалу внаслідок трудової міграції на $46 \%$ обумовлені невідповідністю оплати праці в країнах Європейського союзу та України;

- за останні п’ять років лише два чинники, «міграційні настрої українців» та «доступність мігрантів до соціального страхування» мають позитивні тенденції та в незначній мірі стримують зростання ризику, відповідно, на 3.3 та 4.4\%.

Узагальнений індекс зміни ризиків в трудовій сфері за умови структурних трансформацій в сфері зайнятості за 2013-2018 рр. представлено в Таблиці 1.

Таблиця 1. Зміна субіндексів ризиків трудової сфери внаслідок трансформацій на ринку праці за 2013-2018 рр.

\begin{tabular}{|c|c|c|}
\hline Складові формування ризиків в трудовій сфері & $\begin{array}{c}\text { Ваговий } \\
\text { коефіцієнн } \\
\left(W_{i}\right)\end{array}$ & $\begin{array}{c}\text { Субіндекси } \\
\text { зміни ризиків } \\
\left(I_{i}\right)\end{array}$ \\
\hline Зміна зайнятості внаслідок деіндустріалізації економіки & 0.349 & 1.053 \\
\hline Незахищена зайнятість & 0.1747 & 0.9885 \\
\hline Зниження ефективності витрат робочої сили & 0.349 & 1.016 \\
\hline Незахищеність оплати праці & 0.021 & 1.035 \\
\hline Втрати освітнього потенціалу та людського капіталу & 0.021 & 1.113 \\
\hline $\begin{array}{l}\text { Втрати освітнього, трудового потенціалу та людського капіталу внаслідок трудової } \\
\text { міграції }\end{array}$ & 0.0853 & 1.105 \\
\hline
\end{tabular}

Узагальнений індекс зміни ризиків в соціально-трудовій сфері внаслідок трансформацій на ринку праці за 2013-2018 pp.:

$$
\begin{aligned}
& \mathrm{I}_{\text {соц.риз. }}=1.053^{0.349} \cdot 0.9885^{0.1747} \cdot 1.016^{0.349} \cdot 1.035^{0.021} \cdot 1.113^{0.021} \cdot 1.105^{0.0853}= \\
& =1.0182 \cdot 0.998 \cdot 1.0056 \cdot 1.00073 \cdot 1.0023 \cdot 1.0086=1.034, \text { або } 103.4 \% .
\end{aligned}
$$

Внаслідок трансформації на ринку праці та в системі соціально-трудових відносин ризики в трудовій сфері за 2013-2018 рр. зросли на 3.4\%. За наведеними розрахунками найбільші ризики визначилися за складовими, за якими простежуються втрати освітнього потенціалу, та, як наслідок, людського капіталу як на вітчизняному ринку праці, так і за рахунок трудової міграції. Зростання ризиків за цими складовими за останні п'ять років склало $11.3 \%$ та $10.5 \%$. Близько $1.6 \%$ приросту ризиків обумовлено зниженням ефективності використання робочої сили, а 3.3\% приросту пов'язане з регресивною мобільністю зайнятості внаслідок деіндустріалізації економіки. Лише за одним видом ризиків, що визначає рівень захищеності зайнятості, за останні п’ять років склалася незначна позитивна тенденція, тобто має місце незначне його зниження (на 1.15\%), що в основному обумовлено зниженням загального рівня зайнятості в неформальному секторі, незначним падінням рівня прекарізації ЕАН та зменшенням частки працівників, які працюють неповний робочій день та які перебувають в відпустках без збереження заробітної плати.

Апробація розробленої авторами статті методики оцінки ризиків соціально-економічної незахищеності зайнятих показала, що основними чинники, що обумовлюють суттєве зростання рівнів соціальних ризиків, виникають за умови структурних трансформацій на ринку праці та в національній економіці $\epsilon$ такі:

- деіндустріалізація національної економіки супроводжується регресивною мобільністю зайнятих, втратою мотивації для професійного розвитку; 
- трансформація структури зайнятості формує ризики нераціональноїзайнятості, якісупроводжується зниженням зайнятості в високотехнологічних та знаннєємних видах діяльності;

- низький рівень продуктивності праці та негативні тенденції ї̈ зміни;

більш високим рівнем продуктивної праці;

- зміна зайнятості за освітньо-професійним рівнем супроводжується суттєвою втратою освітнього потенціалу на внутрішньому ринку праці;

- зменшення ризику незахищеної зайнятості, яке одночасно супроводжується суттєвим зростанням рівнів безробіття працездатного населення;

- с суттєве зростання частки працівників, які не охоплені колективними договорами, супроводжується збільшенням ризиків незахищеної зайнятості;

- зменшення рівня неформальної зайнятості в цілому одночасно супроводжується негативними тенденціями в зростанні неформальної зайнятості молоді та спеціалістів вищої кваліфікації;

- посилення зростання міжпоколінського розриву зайнятого населення на користь старших вікових груп;

- збільшення ризику незахищеності оплати праці в найбільшій мірі обумовлено падінням частки оплати праці ВВП та збільшенням питомої ваги працівників, яким нарахована заробітна плата в межах мінімальної;

- суттєве зростання ризику втрати освітнього потенціалу зайнятого населення внаслідок незатребуваності на внутрішньому ринку праці та неформальної зайнятості працівників з вищою освітою;

- зростання ризиків в трудовій сфері внаслідок трудової міграції супроводжується значною втратою трудового та освітнього потенціалу країни та зниженням рівнів соціальної захищеності трудових мігрантів.

Отже, оцінка структурних зрушень у сфері зайнятості та негативні наслідки їх прояву свідчать про наявність та поглиблення кризових явищ на ринку праці, у соціально-трудовій сфері та в національній економіці в цілому. Це є підставою для песимістичних прогнозів розвитку країни, де втрачається трудовий потенціал та людський капітал. Поглиблюється розрив з розвиненими країнами у конкурентоспроможності, цифровому та соціальному розвитку, у захищеності людини праці. Зростають перешкоди для євроінтеграційних процесів.

Кількісна оцінка зміни рівнів соціальних ризиків забезпечує можливість вирішення низки завдань, пов'язаних як з визначенням основних закономірностей та тенденцій їх зміни, так і з детальною ідентифікацією та рівнем впливу окремих чинників такої зміни. Такі оцінки виступають науковим обгрунтуванням ефективних управлінських рішень щодо попередження прояву ризиків та мінімізації негативних наслідків за умови їх реалізації.

\section{AUTHOR CONTRIBUTIONS}

Conceptualization: Olga Novikova.

Data curation: Larysa Shamileva.

Formal analysis: Larysa Shamileva.

Funding acquisition: Olga Novikova.

Investigation: Olga Novikova, Larysa Shamileva.

Methodology: Olga Novikova.

Project administration: Olga Novikova.

Resources: Larysa Shamileva.

Software: Larysa Shamileva.

Supervision: Olga Novikova.

Validation: Larysa Shamileva.

Visualization: Larysa Shamileva.

Writing - original draft: Olga Novikova, Larysa Shamileva.

Writing - review \& editing: Olga Novikova. 


\section{СПИСОК ЛІТЕРАТУРИ}

1. Antonyuk, V., \& Shchetinina, L. (2018). Transformation of employment: methodological foundations of research and european trends. Social and labour relations: theory and practice, 1(15), 77-90. (In Ukrainian). Retrieved from https://ir.kneu.edu.ua/handle/2010/24756

2. Azmuk, N. (2019). Transformatsiia zainiatosti pry perekhodi do tsyfrovoi ekonomiky: hlobalni vyklyky ta stratehii adaptatsii [Transforming Employment in the Transition to the Digital Economy: Global Challenges and Adaptation Strategies] (335 p.). Kyiv: Znannya. (In Ukrainian)

3. Grishnova, O. (2017). Maibutnie pratsi i pratsivnyka v informatsiinomu suspilstvi [The future of labor and employee in the information society]. Imperatyvy ta innovatsiini mekhanizmy zabezpechennia hidnoi pratsi v umovakh stanovlennia novoi ekonomiky: zbirnyk tez dopovidei uchasnykiv Mizhnarodnoi naukovo-praktychnoi konferentsii - Imperatives and innovative mechanisms for decent work in the context of a new economy: a collection of abstracts of participants of the International Scientific and Practical Conference (pp. 25-26). Kyiv: KNEU. (In Ukrainian)

4. Ilich, L. (2017). Strukturni transformatsii tranzytyvnoho rynku pratsi Ukrainy [Structural transformations of the transitive labor market of Ukraine] (608 p.). Alerta. (In Ukrainian). Retrieved from https://idss.org.ua/monografii/Illich_LM_mono_2017.pdf

5. Ilich, L., \& Sarioglo, V. (2019). Statistical modeling of skills mismatch in the labor market. Demography and social economy, 4(38), $42-57$. (In Ukrainian). https://doi.org/10.15407/dse2019.04.042

6. Kolot, A., \& Gerasimenko, O. (2018). Latest global trends in the area of employment and income and their impact on social inequality. Social and labour relations: theory and practice, 1(15), 8-35. (In Ukrainian). Retrieved from https://ir.kneu.edu.ua/bitstream/ handle/2010/24730/6-33K.pdf?sequence=3\&isAllowed=y

7. Kolot, A., \& Gerasimenko, O. (2019). Social and labor development in the xxi century: to the nature of global changes, new opportunities, limitations and challenges. Demography and social economy, 1(35), 97-125. (In Ukrainian). https://doi.org/10.15407/dse2019.01.097

8. Libanova, E. (2018). External labor migration of Ukrainians: scale, causes, consequences. Demography and social economy, 2(33), 11-26. (In Ukrainian). Retrieved from https://dse.org.ua/arhcive/33/1.pdf

9. Libanova, E. (Ed.) (2016). Liudskyi rozvytokv Ukraini. Innovatsiini vydy zainiatosti ta perspektyvy yikh rozvytku [Human development in Ukraine. Innovative types of employment and prospects for their development] (328 p.). Kyiv: Instytut demohrafii ta sotsialnykh doslidzhen im. M. V. Ptukhy NAN Ukrainy. (In Ukrainian). Retrieved from https://www.idss.org.ua/monografii/2017_lud_rozvytok.pdf

10. Lisogor, L. (2016). The European experience of workforce demand forecasting in the context of innovative prospects for transformation of employment in Ukraine. Rynok pratsi ta zainiatist naselennia - Labor market and employment of the population, 1, 17-20. (In Ukrainian). Retrieved from http://nbuv.gov.ua/UJRN/rpzn_2016_1_5

11. NAS of Ukraine (2018). Ukrainske suspilstvo: mihratsiinyi vymir [Ukrainian society: a migration dimension] (397 p.). Kyiv: Ptoukha Institute for Demography and Social Studies of the National Academy of Sciences of Ukraine. (In Ukrainian). Retrieved from https://www.idss. org.ua/arhiv/Ukraine_migration.pdf

12. Novikova, O., \& Shamileva, L. (2019). Social justice in the processes of forced resettlement: evaluation and priorities of achievement. Demography and social economy, 2(36), 109-120. (In Ukrainian). https://doi.org/10.15407/dse2019.02.109

13. Petrova, I., \&. Bliznyuka, V. (2016). Rozvytok sotsialno-trudovoi sfery Ukrainy: teoriia, praktyka, perspektyvy [Development of social and labor sphere of Ukraine: theory, practice, prospects] (326 p.). Kyiv: Institut ekonomiki ta prognozuvannya NAN Ukrainy. (In Ukrainian). Retrieved from https://library.krok.edu.ua/ua/kategoriji/monografiji/476-rozvytok-sotsialnotrudovoi-sfery-ukrainy-teoriia-praktykaperspektyvy

14. Sadova, U. (Ed.) (2019). Ukrainska mihratsiia v umovakh hlobalnykh i natsionalnykh vyklykiv XXI stolittia [Ukrainian migration in the face of global and national challenges of the 21st century] (110 p.). Lviv: Institute of Regional Researchnamed after M.I. Dolishniy of the NAS of Ukraine. (In Ukrainian). Retrieved from http://ird.gov.ua/irdp/p20190801.pdf

15. Saienko, Yu. (Ed.) (2004). Metodolohiia ta metodyka vyznachennia intehralnykh sotsialnykh pokaznykiv [Methodology and methodology for determining integrated social indicators] (372 p.). Kyiv: Institut sociologii NAN Ukrainy. (In Ukrainian)

16. Shamileva, L., Anisimova, G., \& Panasenko, I. (2015). Kilkisni metody v sotsiolohichnykh doslidzhenniakh [Quantitative methods in sociological research] (206 p.). Vinnytsia: TOV «Nilan-LTD». (In Ukrainian) 